\title{
THE RELATIONSHIP BETWEEN FOOT INDEX AND STATURE IN KERALA POPULATION- A DESCRIPTIVE STUDY
}

\author{
Sheik Shakeer Hussain $S^{1}$, Balachandran Ajay² \\ ${ }_{1}^{1}$ Assistant Professor, Department of Forensic Medicine, Government Medical College, Thrissur. \\ 2Professor, Department of Forensic Medicine, Amrita Institute of Medical Sciences, Kochi, Amrita University, India.
}

\section{ABSTRACT}

\section{BACKGROUND}

No published formulae for estimating the stature from foot index were available for the population of Kerala at the time of the study. There was a need to develop such formulae for the local population.

The aim of the study is to-

1. Derive regression equations to estimate the stature from the foot index.

2. Analyse whether it is possible to determine the sex from foot index.

\section{MATERIALS AND METHODS}

The stature and the foot index of the 224 dead bodies of Keralites (167 males and 57 females) aged between 20 and 60 years brought for autopsy at a teaching hospital in Kerala during the period of study were recorded. The foot index is derived by dividing the foot breadth by foot length and multiplying it by 100 .

Statistical Analysis- Linear step wise regression analysis was done. Regression equations for estimating stature were derived from the foot index.

\section{RESULTS}

There was statistically significant difference between males and females with respect to the parameters under study. It is also possible to estimate the sex from foot index.

\section{CONCLUSION}

It is apparent that those having a foot index of more than 44.30 are females. The correlation coefficient between stature and right foot index of females was the only relation, which was not statistically significant as per this study. Other correlations were significant.

\section{KEYWORDS}

Correlation Coefficients, Foot Index, Regression Analysis, Stature Estimation, Sex Determination, T-Test.

HOW TO CITE THIS ARTICLE: Hussain SSS, Ajay B. The relationship between foot index and stature in Kerala population- A descriptive study. J. Evolution Med. Dent. Sci. 2017;6(73):5221-5224, DOI: 10.14260/Jemds/2017/1134

\section{BACKGROUND}

Stature and sex are two of the important primary parameters in establishing the identity of a person. ${ }^{1}$ In mass disasters, the identification of the victim is of paramount importance when only fragmented body parts are available. Such scenarios are frequently encountered in medicolegal practice.

The measurement of most of the body parts are related to the stature. It can be estimated from hand, foot or shoe prints left at the scene of crime. ${ }^{2,3,4,5,6,7}$ It is possible to estimate the stature when the foot is the only part of the body that remains. ${ }^{8,9}$ Studies have shown that the footprint ratio has a relationship with the sex of the individual as well.

Despite the relationship between stature and body parameters, it is important to remember that they vary from population to population and in different ethnic groups due to the differences in genetics, 10 nutrition and levels of physical activity. ${ }^{11,12,13}$ Hence, it is important to find out these relationships in different ethnic groups/population.

Financial or Other, Competing Interest: None.

Submission 02-08-2017, Peer Review 27-08-2017,

Acceptance 01-09-2017, Published 11-09-2017.

Corresponding Author:

Dr. Balachandran Ajay,

Professor, Department of Forensic Medicine,

Amrita Institute of Medical Sciences,

Kochi, Amrita University, India.

E-mail:drajay1976@yahoo.com

DOI: $10.14260 /$ jemds $/ 2017 / 1134$
Mathematical methods of stature estimation including linear regression as used by Trotter and Gleser in $1952^{14}$ makes use of the relationship between the size of a bone and the stature of the individual. Regression analysis yield formulae, which can be used to estimate stature from unidentified body remains.

In India, there are many studies available, which attempt to estimate the stature from long bones dating back to Pan who published in 1924.15 But, only a few of them, attempted to determine sex from measurements of body parts, especially that of foot.

Rutishauser, in an article published in 1968 had showed that it is possible to estimate stature from the foot length. ${ }^{16} \mathrm{~A}$ study ${ }^{17}$ published in 1990, in which the footprints of 250 Dakshina Kannada villagers walking barefoot were analysed showed a higher footprint ratio in males. Sex could be established with an accuracy of $78 \%$ by this method. A study published in 200718 based on the foot dimensions of 250 students from Mauritius (125 males and females) above the age of 18 years showed that the foot index was more than 37 for females and less than 37 in males, which can be used as deviation point for the determination of sex.

A study ${ }^{19}$ published in 2009 determined the sex from length and breadth of footprint and foot index in hundred subjects 50 of each sex in South Indian population found that even though the foot index was higher in males, it could not be used for sex determination. 
The published research indicates the possibility that regression equations for estimating stature can be derived from foot index. It was also possible that foot index could be used for determination of sex. There are a lot of variations in estimating stature from foot measurements among people of different regions and race as the above studies indicate. The authors feel the necessity for creating formulae aimed at estimation of stature and determination of sex from dismembered body parts for the population of the state of Kerala.

\section{Aims}

Our attempt was to derive formulae to estimate the stature from the foot index of Keralites. We also attempted to analyse whether it was possible to determine sex of Keralites from foot index.

\section{MATERIALS AND METHODS}

This study was conducted from November 2010 to November 2011. During this time, the lead investigator measured the stature and the breadth and length of feet of 224 dead bodies of Keralites aged between 20 and 60 years brought for autopsy in the Department of Forensic Medicine at Medical College, Thiruvananthapuram. 167 of these were males and 57 were females. The exclusion criteria were the following- a) Significant congenital or acquired deformities including fractures of spinal column and long bones; b) Segmented, charred, mutilated and decomposed bodies; c) History of nutritional deficiency, abnormal growth pattern and hormonal imbalance; d) Those who were not residents of Kerala.

The following parameters were recorded as stated below.

The stature was measured using a two meter long steel scale fixed to a straight wooden pole as the straight distance in centimetres from the heel to vertex when the body is placed on a horizontal surface in supine position in the Frankfurt plane with a wooden block kept at the head end and a wooden board kept at the foot end, see fig. 1.

The foot length was measured as the distance from the most prominent part of the heel (Pternion) to the most distal part (Acropodian) of the first or second toe whichever was longer when the foot was placed firmly on the wooden board using a Mitutoyo digital sliding caliper having an accuracy of $0.01 \mathrm{~mm}$ with the body placed in supine position on a horizontal surface and the foot kept perpendicular using a flat board, see fig. 2 .

The foot breadth was measured as the straight distance in millimetres from the most medially placed point on the head of the first metatarsal to the most laterally placed point on the head of fifth metatarsal using the digital sliding calliper, see fig. 3.

The research was designed as a descriptive crosssectional study. Statistical analysis was done using SPSS version 16.0. The collected data were subjected to linear stepwise regression analysis to predict sex and stature from foot index. As part of regression analysis, Pearson's product moment coefficient of correlation was done. In addition, paired sample t-test and independent sample t-test (Student's t-test) was also applied in order to find out whether there is any significant difference between right and left foot indices. Data were analysed separately for males and females.

\section{RESULTS}

The range of foot indices are given in Table 1. Regression equations were calculated for predicting stature $(\mathrm{Y})$ from right foot index for the males and females separately. The right foot index $\left(\mathrm{X}_{1}\right)$ was calculated by the following formula.

$$
\text { Right foot index }=\frac{\text { Right foot breadth }}{\text { Right foot length }} \times 100
$$

The mean right foot index for males is 38.49. The minimum right foot index is 32.97 and maximum is 43.52 . The correlation coefficient between stature and right foot index is -0.308 . It is significant at 0.01 level. The regression equation to estimate stature derived from the right foot index of males is given in Table 2. The obtained $\mathrm{F}$ value $(\mathrm{F}=17.31$; $\mathrm{p}<0.01$ ) is significant at 0.01 level, which shows that the regression model is highly significant.

The mean right foot index for females is 37.78 . The minimum right foot index is 32.03 and maximum is 45.24 . The correlation coefficient between stature and right foot index is -0.240 . It is not significant at any level. The regression equation to estimate stature derived from the right foot index of females is given in Table 2. The obtained $\mathrm{F}$ value $(F=3.37 ; p<0.01)$ is significant at 0.01 level, which shows that the regression model is significant. Similarly, a regression equation was calculated for predicting stature from left foot index $\left(\mathrm{X}_{2}\right)$. The left foot index was calculated by the following formula.

$$
\text { Left foot index }=\frac{\text { Left foot breadth }}{\text { Left foot length }} \times 100
$$

The mean left foot index for males is 38.60 . The minimum left foot index ICS 33.69 and maximum is 44.30. The correlation coefficient between stature and left foot index is 0.203 . It is significant at 0.01 level. The regression equation derived from the left foot index of males is given in Table 2 . The obtained $F$ value $(F=7.10 ; p<0.01)$ is significant at 0.01 level, which shows that the regression model is highly significant.

The mean left foot index for females is 37.72. The minimum left foot index is 33.01 and maximum is 44.69 . The correlation coefficient between stature and left foot index is 0.261 . It is significant at 0.05 level. The regression equation derived from the left foot index of females is given in Table 2 . The obtained $F$ value $(F=4.03 ; p<0.01)$ is significant at 0.01 level, which shows that the regression model is significant.

The foot index of males and females are shown in Table 1. It was observed that females have got higher foot index. It is apparent that those having a foot index of more than 44.30 are females.

To test the reliability of the derived equation in the reallife scenario, they were applied on two randomly selected dead bodies, which were not part of the sample; one a male and the other a female.

On the male body, the stature estimated using the right foot index was $166.18 \mathrm{~cm}$. From the left foot index, it was 
$166.52 \mathrm{~cm}$. The actual height of the individual was $171 \mathrm{~cm}$. On the female body, the stature was estimated to be $153.41 \mathrm{~cm}$ using the right foot index and it was $153.81 \mathrm{~cm}$ from the left foot index. The measured stature of the individual was 157 $\mathrm{cm}$.

This demonstrates that the equation is fairly accurate in predicting the stature. A reliable assessment of sex can be done using the parameters derived from the study.

\begin{tabular}{|c|c|c|}
\hline & Male & Female \\
\hline Right foot index & $32.97-43.52$ & $32.03-45.24$ \\
\hline Left foot index & $33.69-44.30$ & $33.01-44.69$ \\
\hline \multicolumn{2}{|c|}{ Table 1. Foot Index of Males and Females } \\
\hline
\end{tabular}

\begin{tabular}{|r|c|c|}
\hline & Male & Female \\
\hline Right foot index & $\mathrm{Y}=208-1.109 \mathrm{X}_{1}$ & $\mathrm{Y}=178.955-0.624 \mathrm{X}_{1}$ \\
\hline Left foot index & $\mathrm{Y}=192.404-0.6929 \mathrm{X}_{2}$ & $\mathrm{Y}=182.309-0.714 \mathrm{X}_{2}$ \\
\hline $\begin{array}{r}\text { Table 2. Regression Formula Derived } \\
\text { from the Foot Index of Males and Females }\end{array}$ \\
\hline
\end{tabular}

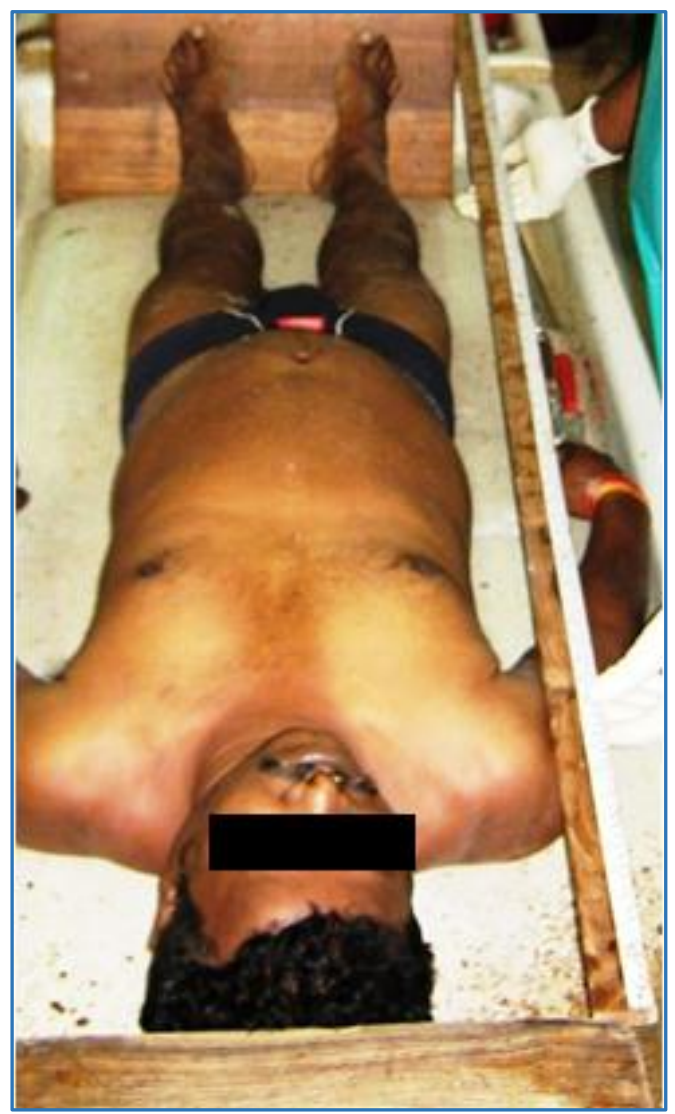

Figure 1. The Method of Measuring the Stature

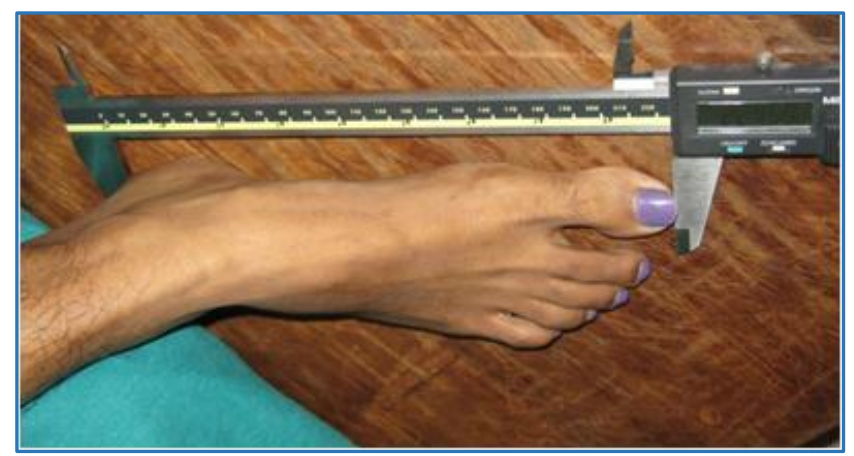

Figure 2. The Method of Measuring the Foot Length

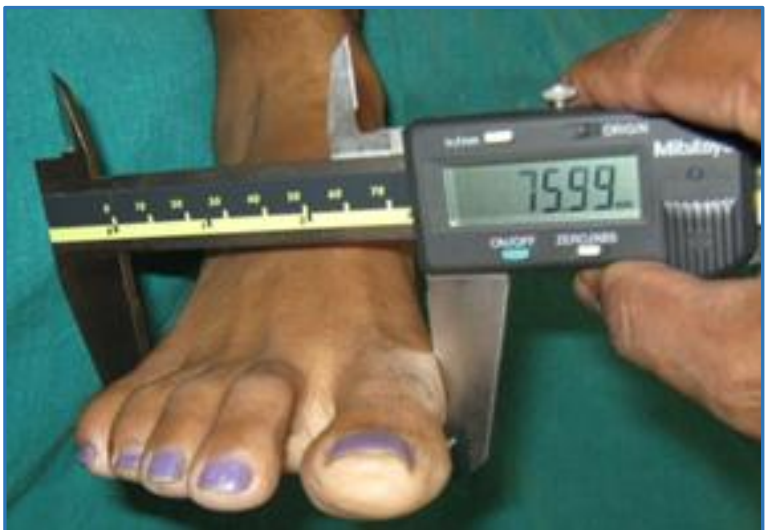

Figure 3. Method of Measuring the Foot Width

\section{DISCUSSION}

The present study was an attempt to determine the sex and stature from foot index.

The correlation coefficient between stature and right foot index of females was the only relation, which was not statistically significant as per this study, even though the regression equation derived from the right foot index of females to estimate stature was significant at 0.01 level. The relationship between stature and all the other foot index values obtained in the present study were positive and significant for males as well as females. The regression formulae could be very helpful in deriving an accurate estimate of stature when the foot length and breadth are available.

\section{CONCLUSION}

As per the study, those with the foot index of more than 44.30 are females. An assessment of sex can be done using this finding. This was at variance with other published studies on other populations. One such study had determined that the cutoff for sex determination was 37.0, above which the individual could be identified as a female. ${ }^{18}$ In another study, ${ }^{19}$ the males had higher foot index compared to females, even though, it was not statistically significant.

\section{REFERENCES}

[1] Mathiharan K, Patnaik AK. Personal identity: Modi's medical jurisprudence and toxicology. 23rd edn. Lexis Nexis Butterworth's, 2005:264-5.

[2] Saxena SK. A study of correlations and estimation of stature from hand length, hand breadth and sole length. Anthropol Anz 1984;42(4):271-6.

[3] Robbins LM. Estimating height and weight from size of footprints. J Forensic Sci 1986;31(1):143-52.

[4] Giles E, Vallandigham PH. Height estimation from foot and shoeprint length. J Forensic Sci 1991;36(4):113451.

[5] Jasuja OP, Singh J, Jain M. Estimation of stature from foot and shoe measurements by multiplication factors: a revised attempt. Forensic Sci Int 1991;50(2):203-15.

[6] Gordon CC, Buikstra JE. Linear models for the prediction of stature from foot and boot dimensions. J Forensic Sci 1992;37(3):771-82. 
[7] Ashizawa K, Kumakura C, Kusumoto A, et al. Relative foot size and shape to general body size in Javanese, Filipinas and Japanese with special reference to habitual footwear types. Ann Hum Biol 1997;24(2):117-29.

[8] Lundy JK, Feldesman MR. Revised equations for estimating living stature from the long bones of the South African Negro. S Afr J Sci 1987;83:54-5.

[9] Ozaslan A, Ișcan MY, Ozaslan I, et al. Estimation of stature from body parts. Forensic Sci Int 2003;132(1):40-5.

[10] Jelenkovic A, Hur YM, Sund R, et al. Genetic and environmental influences on adult human height across birth cohorts from 1886 to 1994. eLife 2016;5:e20320.

[11] Malina RM. Physical activity and training: effects on stature and the adolescent growth spurt. Med Sci Sports Exerc 1994;26(6):759-66.

[12] Benefice E, Garnier D, Ndiaye G. High levels of habitual physical activity in west African adolescent girls and relationship to maturation, growth, and nutritional status: results from a 3-year prospective study. Am J Hum Biol 2001;13(6):808-20.
[13] Damsgaard R, Bencke J, Matthiesen G, et al. Body proportions, body composition and pubertal development of children in competitive sports. Scand J Med Sci Sports 2001;11(1):54-60.

[14] Trotter M, Gleser GC. Estimation of stature from long bones of American Whites and Negroes. Am J Phys Anthropol 1952;10(4):463-514.

[15] Pan N. Length of long bones and their proportion to body height in Hindus. J Anat 1924;58(Pt 4):374-8.

[16] Rutishauser IH. Prediction of height from foot length: use of measurement in field surveys. Arch Dis Child 1968;43(229):310-2.

[17] Rao NG, Kotian S. Footprint ratio (FPR)-a clue for establishing sex identity. J Ind Acad Forensic Med 1990;12:51-6.

[18] Agnihotri AK, Shukla S, Purwar B. Determination of sex from foot measurements. Internet J Forensic Sci 2007;2(1).

[19] Vidya CS, Shamasundar NM, Manjunatha B, et al. Study of footprints for sex determination in the South Indian population. Journal of South Indian Medicolegal Association 2009;1(2):49-52. 